\title{
THE MEANING OF INCOME IN THE PERSPECTIVE OF UMROH AND HAJJ TRAVEL ENTREPRENEUR
}

\author{
Akbari Yuliandra Andar*, Ludigdo Unti, Mulawarman Aji Dedi \\ Faculty of Economics and Business, University of Brawijaya, Indonesia \\ ${ }^{*}$ E-mail: andraandar@gmail.com
}

\begin{abstract}
This study aims to find the meaning of income according to Umrah and Hajj travel entrepreneurs. This research uses qualitative research with transcendental phenomenology approach. Based on the searching results, it can be found three meanings of income for Umrah and Hajj travel, namely material income, social income and spiritual income. Each income has its own uniqueness and gives the influences to the Umrah and Hajj travel. These findings indicate that the existence of the three incomes forms something called the Hajj and Umroh Travel Triangle which ultimately builds and shapes the Umrah and Hajj travel into a complete and lively business.
\end{abstract}

\section{KEY WORDS}

Income meaning, Umrah and Hajj travel, phenomenology, business.

In depth and comprehensive exploration of income has evolved over time. This is due to the importance of income as a component in a business as previously explained. Research on income from the level of concept to the meaning has also been carried out ranging from non-income entities to certain professions by using various research methodologies. Some research shows income has been freed from the definition of the material alone. As conducted by Purnamasari (2009) by searching for the meaning of income for educational foundations. Purnamasari (2009) found that there are three meanings of "income" for educational foundations, namely material income, social income and memorable income. The researcher believes that the three meanings of "income" have their own uniqueness and have an impact on the educational institution. Purnamasari (2010) also conducted other research by carrying out the meaning of "income" for the medical profession. Purnamasari (2010) found that there are four meanings of income in the medical profession, namely material benefits, spiritual benefits, dignity benefits and the benefits of inner satisfaction.

The essence of income that is not always interpreted by the material stated in the Berthoud et al. (2004), Anggraeni's (2015), Verbunt et al. (2019). In that research income is not always associated with the understanding that has been circulating in general but income also has other meanings in the form of consumer satisfaction, blessings and social. Another meaning that arises is an embodiment from the presence of happy values, altruistic values, brotherhood and spirituality values that exist inside the informant. This is the same as Haerul (2016) who explore the awareness of the meaning of incomes from internet cafe businesses (internet cafes) in Pinrang Regency, South Sulawesi by using the phenomenology methodology and obtained the meaning of income as income, social income, and spiritual income by bringing cultural values that are brought by business actors namely sulapa eppa. The meaning of income revealed in the research is conceptualized in economic, mental, and spiritual values which were previously developed by Triyuwono (2012), Rahe et al. (2019), Stewart \& Roberts (2019), Lansford et al. (2019) which is referred to as sharia added value.

The concept of income has also been deconstructed based on the perspective of the Pancasila, Parikesit (2012) has succeeded in formulating a income concept based on the values contained in each precept/sila in Pancasila. The research produce the concept of income that has been built by Islamic/sharia accounting namely economic, mental, and spiritual income (Triyuwono, 2012: 422-424) as outlined in the third and fourth precepts, the study added the process of earning income (input) lawfully as outlined in the first and second 
precepts, then the process of distributing the incomes (output) as outlined in the fifth precept. Do not stopping only there, research on the concept of income again raised at the level of hospitals that are non-income organizations, Nurindrasari (2016) concocted the concept of welfare as an alternative concept of income in the Tjoet Njak Dhien frame. Then Riduwan (2008) also gives color to the study of income namely reveals the interpretation of income from the perspective of non-accountant business practitioners by using the hermeneutics methodology. The research shows that incomes experience hyperreality namely apart from the actual reality, that there is an expectation gap between the concept of incomes in accounting with stakeholders represented by financial managers, credit analysts, investment advisors, and individual investors. Mulawarman (2014) developed the concept of value added of accounting based on holistic wisdom. The result is value added of accounting has twelve chakras. Accounting is not only limited to siding with stakeholders, but expanding these stakeholders to be pro-people and the environment with God-consciousness based on harmony of faith.

Researches on income above through various in-depth and comprehensive studies have other non-material interpretations. This indicates that income has freed itself from the prison of materialism which has been an inseparable doctrine. Kaimuddin (2012) has conducted tests on incomes perceptions at the level of students who are influenced by spiritual intelligence, the higher the spiritual intelligence of students will provide incomes perceptions that are not only material, but also have aspects beyond the materialistic value and are aware of God's presence. The manifestation of incomes in other aspects seems to return incomes to its essence, but this is not easy because not all economic actors can receive incomes in non material manner, therefore needed an additional studies and very strong belief in each individual.

The use of different informants from the above research is needed in order to obtain a more contradictory meaning extraction because of the diversity in interpreting the incomes. The author believes that the diversity of the meaning of incomes will be obtained from informants who have a business related to matters of worship, which in this case is Hajj and Umrah Travel Company. Hajj and Umroh travel companies were chosen because the Hajj is the fifth pillar of Islam and many opinions have developed that it is not perfect for one's Islam if not to go on the Hajj. Therefore many people try hard so that they can perform the hajj pilgrimage, so there is an Umrah and Hajj travel company in Indonesia that helps realize the wishes of a people to perform the hajj.

Research related to travel and Umrah in Indonesia will be very interesting to be studied, this is based on the dominant number of Muslims in Indonesia. The majorities of citizens in Indonesia who are Muslim practically make Indonesia as the most country in sending pilgrims, then ranked in second Pakistan, then India, Bangladesh and Nigeria. The Indonesian hajj quota since 2013 was cut by $20 \%$ due to the renovation of the Masjidil Haram. However, in 2017, the Indonesian hajj quota returns to normal, which were originally 168.000 members of the congregation to 211.000 members of the congregation. With the addition of this hajj quota, the waiting time for Indonesian pilgrims will be cut, which initially had to wait an average of 17 years, now it will be 14 years. But in reality the business activities of the Umroh and Hajj are not always smooth as the congregation predicts. Often there is a problem inside which in the end will make consumers or pilgrims became the victims. The problem that occurred was the postponement of the departure for both hajj and umroh pilgrims. Another problem is the existence of fraud under the guise of Umrah and Hajj travel. The use of a qualitative approach in this study is intended to look for the true meaning of income from the perspective of Umrah and Hajj travel entrepreneurs. This approach was chosen because it was considered capable of providing more comprehensive information that could not be explained by the relationship of numbers.

\section{METHODS OF RESEARCH}

This study uses qualitative research, namely research that aims to understand the phenomena experienced by research subjects as a whole by means of descriptions in the 
form of words and languages. Qualitative research collects data in the form of naturalistic verbal reports such as interview manuscripts, then the report form is interpreted in a narrative report on the respondents' perceptions, understandings, and meanings about a phenomenon (Smith, 2009:3).

In an effort to seek understanding of a meaning and concept and how to explore awareness through several stages, researchers use the phenomenology methodology. Phenomenology is a branch of philosophy created by Edmund Husserl. According to Husserl in Kuswarno (2009: 10), phenomenology studies the experiences of others who experience them and it is as if the researchers experienced them. This is realized by how far the informant interprets an object in his experience, a wider meaning than what is seen.

According to Mamulaty et al. (2016), phenomenologists like to see the phenomenon which is the basis of their own lives so that they teach no longer see objects but phenomenon. There are 3 types of phenomenology, namely transcendental phenomenology, existential phenomenology and sociological phenomenology. Researchers use transcendental phenomenology which focuses on the study of consciousness (Kamayanti, 2016: 150). The units of analysis in Husserl's transcendental phenomenology in Kuswarno (2009: 40-46), among others: intentionality is a process in humans related to certain objects that are influenced by pleasure, initial assessment, and expectations of objects. For example, the pleasure of football will determine the intentionality to watch football matches on television. Through this concept, Husserl tried to make the meaning for objects from another point of view. This results in one object actually will have an object in perception which depends on who perceives it, time, judgment, and the best point in taking the meaning.

Based on the intentionality component, it can be seen that meaning is the relationship between the real object and the object in perception. Intentionality is formed by the two of noema and noesis. Noema is something that is captured by the five senses so that the resulting description is what appears in the five senses and is objective. Whereas noesis is the 'subconscious' which makes people think, feel, perceive, and remember. Noesis is subjective because it produces actual meaning from inside the mind of human consciousness, not meaning that appears from the outside. Noema and noesis are interrelated. A true meaning will be taken noema to noesis, because after all the object will be captured by the five senses for the first time then it will be brought to the mind that will reveal the meaning through the whole. The relation between noema and noesis is something real and arises because of experience and not an interpretation (Kamayanti, 2016: 152-153).

Basically, in humans there is an infinite nature that will produce pure perception. What is seen and what is really seen in consciousness are interconnected in intentional action. Ontologically, phenomenology considers truth comes from individual consciousness, pure consciousness without intervention from anywhere.

\section{RESULTS AND DISCUSSION}

Material income for Umrah and Hajj travel has meaning as a means of payment. With material incomes, Umrah and Hajj travel can carry out Umrah and Hajj activities, pay employee salaries and other operational activities as well as for the promotion of Umrah and Hajj travel. In its business activities, then the existence of material income becomes important in Umrah and Hajj travel. Material income is used to develop and advance Umrah and Hajj travel. Starting from equipping themselves with the necessary facilities until the business expansion. Material income is used not for the personal benefit of the owners of Hajj and Hajj travel, but is emphasized on the progress of Umroh and Hajj travel itself.

Social income means that Umrah and Hajj travel is not tempted by the amount of material income. Social income becomes a barrier for Umrah and Hajj travel in its efforts to find material income. Umrah and Hajj travel is not solely pursuing material income, but the most important thing for Umrah and Hajj travel is the existence of this social income. Social income becomes a form of gratitude when material income exists so that it does not forget God who gives it. 
Spiritual income is a form of income that is different from other types of income. However, that does not mean spiritual income is a form of income that is not important and is not related to other forms of income. Spiritual income becomes an added value given by Umrah and Hajj travel as a result of all activities carried out in Umrah and Hajj travel. Spiritual income is a type of income that shows the religious side of accounting income itself. Informants do not view accounting income as a pile of personal assets. They make a income with a sense of sincerity and feel the presence of God in their efforts.

Each type of income does provide a different color and meaning for Umrah and Hajj travel. Each income also influences the actions and decisions of Umrah and Hajj travel. Material income requires Umrah and Hajj travel to meet their needs through material forms. Social income becomes an important income, in addition to limiting the movement of material income, social income shows the direction for Umrah and Hajj travel in running its business. Social income is the most important form of income, considering that this income becomes a guide so that the umrah and hajj travel in its activities does not forget the creator. The latter, spiritual income shows the religious side of accounting income. Informants do not view accounting income as a pile of personal assets. They make a income with a sense of sincerity and feel the presence of God in their efforts.

These three incomes indicate a significant influence on the activities of Umrah and Hajj travel. For example, material incomes make Umrah and Hajj travel impose Umrah and Hajj expenses on pilgrims. But with the social income, the costs charged to the congregation turned out to be felt by others who could not afford so that they could also feel going to the holy land. Spiritual incomes make Umrah and Hajj travel more motivated to provide the best for each of its stakeholders. Each income has a unique influence and forms a pattern in the activities of Umrah and Hajj travel.

The influence given by these three incomes cannot be compared. All incomes have a unique influence on the continuation of Umrah and Hajj travel activities. It cannot be said which is the most important and which are not. Meaning that, this income must be fostered in accordance with their needs so that umrah and Hajj travel can continue to grow as desired. The three different incomes provide colorful life forms in Umrah and Hajj travel. With the different types of incomes, it shows that Umrah and Hajj travel are able to carry out their duties in every aspect of life. Every aspect has different meanings and unique influences for Umrah and Hajj travel. With the existence of a circle of income in Umrah and Hajj travel shows a balance among incomes become the main stuff for Umrah and Hajj travel in carrying out its activities.

In carrying out its activities, Umrah and Hajj travel are always colored by each form of income, whether realized or not. These three forms of income are inherent in all the breaths of Umrah and Hajj travel life. Material income, social income and spiritual income become three forms of income that form each other in an unbroken and endless relationship. Every income has an engagement between one income and another income. This engagement forms an atmosphere in Umrah and Hajj travel. These linkages of engagement are mutually building and complementary so that the Umroh and Hajj travel become a complete business. The one income with the other income is mutually building and can not be separated. The three incomes found in Umrah and Hajj travel cannot stand alone. Every income requires support from other forms of income so that this attachment/ engagement will become natural and continue.

The three incomes that build each other up with one another form the Umrah and Hajj travel becomes a complete business. Material income becomes a form of income which is a necessity in Umrah and Hajj travel. However, the existence of social income is like a reminder for Umrah and Hajj travel so that not to forget the creator and do not view material income as the most essential form of income but as a complement in living the Umrah and Hajj travel. Spiritual income is a form of income that shows the results of the existence of Umrah and Hajj travel as a business engaged in worship. Without material income or social income, there is no spiritual income. There will be no spiritual income without the presence of material income or social income. This connection is what consciously and unconsciously 
forms a income circle in Umrah and Hajj travel. Concretely, the Income Circle of Umrah and Hajj travel can be seen from the following figure:

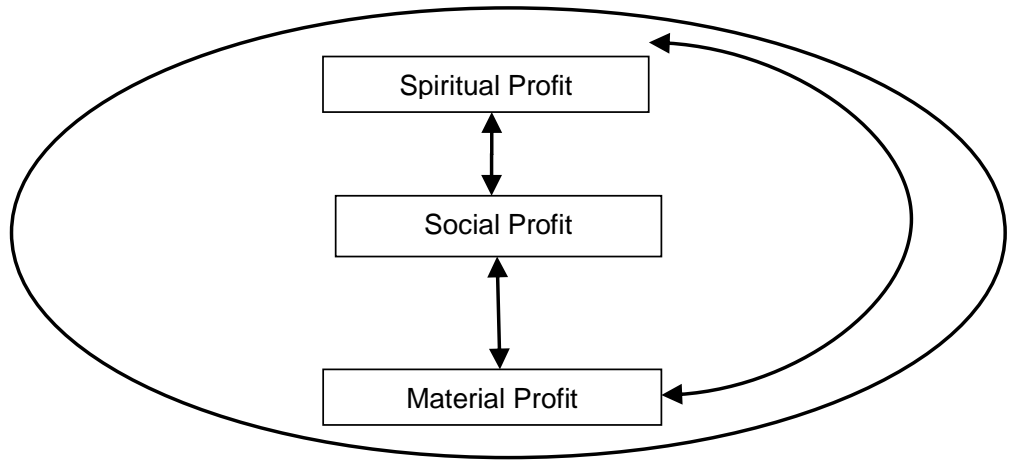

Figure 1 - Umrah and Hajj Travel Income Circle

Figure 1 shows that spiritual motivation produces three incomes, namely material income, social income and spiritual income, where these three meanings have a relationship in Umrah and Hajj travel. Every income is interrelated and has a mutual influence. Relationships among incomes bring influence to other incomes. In Figure 1, it can be seen that social income influences material income, namely as a reminder of the search for material income so that Umrah and Hajj travel does not forget God. But material income also has an influence on social income. Material income provides funds in the implementation of social income of Umrah and Hajj travel to external parties, namely the surrounding communities who are less fortunate.

Material income also affects spiritual income because without material income, Umrah and Hajj travel will be difficult to carry out its activities without funds so that makes spiritual income realized. Spiritual income also provides a reciprocal influence on material incomes in the form of added value offered that will attract prospective worshipers so that material incomes will be obtained. Social income is also inseparable from the existence of spiritual income. Social income provides an opportunity for all worshipers to be able to enjoy the spiritual income offered by Umrah and Hajj travel to all its stakeholders. Spiritual income also provides added value for those who have enjoyed the social income that has been provided by Umrah and Hajj travel.

Every income interconnected with intact, without having the tip and base. The three incomes build on one another and help shape other incomes. The income circle only exists if the three incomes namely material income, social income and spiritual income exist. It is the linkages and engagement / attachment among incomes that build the circle of Umrah and Hajj travel incomes. These three incomes cannot be separated from one another but must build up each other so that the Income Circle of Umrah and Hajj travel can be formed.

The three incomes are indeed interconnected and influence each other. Each form of income becomes the size and limitation of its own for Umrah and Hajj travel. Each form of income also has a close relationship to complement each other so that umrah and hajj travel become a complete business. With the Circle of Income of Umrah and Hajj travel, Umrah and Hajj travel will continue to survive and be able to give what they should give as a business related to worship. The income circle of Umrah and Hajj travel continues to be a link of the success of Umrah and Hajj travel in carrying out its duties and obligations. This income circle of Umrah and Hajj travel that forms the balance of Umrah and Hajj travel in carrying out all its activities.

\section{CONCLUSION}

Through a study of transcendental phenomenology awareness, the researcher has explored informant awareness about the meaning of accounting income. Based on the searching results, then it can be found three meanings of income for Umrah and Hajj travel, 
namely material income, social income and spiritual income. Each income has its own uniqueness and influences Umrah and Hajj travel. Material income is the first meaning of income found in Umrah and Hajj travel. Umrah and Hajj travel interpret the incomes as material driven by the existence of a need, the need to pay for all Umrah and Hajj travel activities. The second meaning of income that has been found is social income. Social income conducted by taking into account the existence of the surrounding community. The existence of social incomes is important to show the social identity of Umrah and Hajj travel. The third meaning of income is spiritual income. This income is a unique form of income and may only be owned by Umrah and Hajj travel Spiritual income becomes an important added value and involves all aspects of Umrah and Hajj travel activities. Spiritual income is the result of various activities carried out by Umrah and Hajj travel.

All three of these incomes have a considerable influence on Umrah and Hajj travel. Each income also affects each other and has the linkage and engagement /attachment to the other incomes. The linkages and engagement among the three incomes form something which called Umrah and Hajj Travel Income Triangle. In reality the Umrah and Hajj Travel Income Triangle shapes and builds and influences Umrah and Hajj travel, for example in the relationship between material and social incomes. Income material makes Umrah and Hajj travel can send pilgrims with the best quality and get a income. However, social income becomes limitation and a reminder for Umrah and Hajj travel in seeking material income by sending people who are worthy and unable with free as their gratitude in obtaining material incomes. Spiritual income cannot be separated from material income or social income. Spiritual income guides Umrah and Hajj travel to continue to develop activities that give a deep impression to all stakeholders.

These findings indicate that the existence of the three incomes form something called the Umrah and Hajj Travel Income Triangle. Realized or not, the Umrah and Hajj Travel Income Triangles owned by Umrah and Hajj travel coloring every movement and step of Umrah and Hajj travel. The Umrah and Hajj Travel Income Triangle is a profound thing that is owned by Umrah and Hajj travel which ultimately builds and shapes Umrah and Hajj travel into a complete and lively business.

\section{REFERENCES}

1. Anggraeni, R.D. 2015. Menggali Makna Income Dari Pengusaha Muslim: Studi Semi Biografi. Universitas Brawijaya Malang.Tesis.

2. Berthoud, R., Bardasi, E., Bryan, M. L., \& Britain, G. 2004. The dynamics of deprivation: the relationship between income and material deprivation over time (No. 219). Corporate Document Services.

3. Haerul. 2016. Sulapa Eppa: Kesadaran Tentang Makna Laba Usaha Kecil Fals Komputer. Tesis. Jurusan Akuntansi, Fakultas Ekonomi and Bisnis. Universitas Brawijaya.

4. Kaimuddin, S.N. 2012. "Pengaruh Kecerdasan Emosional and Kecerdasan Spiritual terhadap Persepsi Laba (Studi pada Mahasiswa Akuntansi).Skripsi. Jurusan Akuntansi. Fakultas Ekonomi Universitas Hassanudin.

5. Kamayanti, A. 2016. Metodologi Penelitian Kualitatif Akuntansi. Pengantar Religiositas Keilmuan. Cetakan pertama. Jakarta Selatan: Yayasan Rumah Peneleh.

6. Kuswarno, E. 2009. Metodologi Penelitian Komunikasi, Fenomenologi (Konsepsi,Pedoman, and Contoh Penelitiannya). Bandung: Widya Padjajaran.

7. Lansford, J. E., Malone, P. S., Tapanya, S., Tirado, L. M. U., Zelli, A., Alampay, L. P., Deater-Deckard, K. 2019. Household income predicts trajectories of child internalizing and externalizing behavior in high-, middle-, and low-income countries. International journal of behavioral development, 43(1), 74-79.

8. Mamulaty, I., Triyuwono, I., Mulawarman, A. D. 2016. Fenomenologi Sumber Daya Manusia sebagai Aset Intelektual dalam Amal Usaha Muhammadiyah. Jurnal akuntansi and Investasi Vol. 17 No. 1. 
9. Mulawarman, A.D. 2014. On Holistic Wisdom Core Datum Accounting: Shifting From Accounting Income To Value Added Accounting. The International Journal of Accounting and Business Society Vol 22, No 1.

10. Nurindrasari, D. 2016. Konsep Kesejahteraan: Alternatif "Laba" Rumah Sakit dalam Bingkai Tjoet Njak Dhien. Skripsi. Jurusan Akuntansi. Fakultas Ekonomi and Bisnis. Universitas Brawijaya.

11. Parikesit, B.S. 2012. "Dekonstruksi Laba dalam Perspektif Pancasila". Skripsi. Jurusan Akuntansi. Fakultas Ekonomi and Bisnis.Universitas Brawijaya.

12. Purnamasari, D. 2009. Tafsir Hermeneutika Intensionalisme Atas Laba Yayasan Pendidikan. Jurnal Akuntansi Multiparadigma. Vol. 1 No. 3.

13. Purnamasari, D. 2010. Tafsir "Keuntungan" Bagi Profesi Dokter denganPendekatan Hermeneutika Intensionalisme. Simposium Nasional Akuntansi XIII. Purwokerto.

14. Rahe, M. L., Weber, B., Wu, X., \& Fisher, M. 2019. Income Inequality and County Economic Resistance to Job Loss during the Great Recession. Review of Regional Studies, 49(1), 129-147.

15. Riduwan, A. 2008. Realitas Referensial Laba Akuntansi sebagai Refleksi Kandungan Informasi (Studi Interpretif-Kritis dari Komunitas Akuntan and Non-Akuntan). Simposium Nasional Akuntansi XI. Pontianak.

16. Smith, J. A. 2009. Psikologi Kualitatif Panduan Praktis Metode Riset. Yogyakarta: Pustaka Belajar.

17. Stewart, K., \& Roberts, N. 2019. Child poverty measurement in the UK: assessing support for the downgrading of income-based poverty measures. Social Indicators Research, 142(2), 523-542.

18. Subiyantoro, E.B. and I. Triyuwono, 2004. Laba Humanis: Tafsir Sosial atas Konsep Laba dengan Pendekatan Hermeneutika. Bayumedia. Malang.

19. Triyuwono, I. 2013. Makrifat Metode Penelitian Kualitatif and Kuantitatif Untuk Pengembangan Disiplin Akuntansi.Simposium Nasional Akuntansi XVI. Manado.

20. Triyuwono, I. 2012. Akuntansi Syariah Perspektif, Metodologi, and Teori. Jakarta: PT. Raja Grafindo Persada.

21. Verbunt, P., \& Guio, A. C. 2019. Explaining Differences Within and Between Countries in the Risk of Income Poverty and Severe Material Deprivation: Comparing Single and Multilevel Analyses. Social Indicators Research, 144(2), 827-868.

22. Widaryanti. 2009. Analisis Perataan Laba and Faktor-Faktor Yang Mempengaruhi Pada Perusahaan Manufaktur Di Bursa Efek Indonesia. Fokus Ekonomi. Vol. 4 No. 2. pp: 60-77.

23. Yocelyn, A. and Yulius, J.C. 2012. Analisis Pengaruh Perubahan Arus Kas and Laba Akuntansi Terhadap Return Saham pada Perusahaan Berkapitalisasi Besar. Jurnal Akuntansi and Keuangan Petra. Vol.14 No. 2. 